Article

\title{
Comprehensive Value Discovery of Land Consolidation Projects: An Empirical Analysis of Shanghai, China
}

\author{
Yishao Shi ${ }^{1, *(\mathbb{D})}$, Xiangyang Cao ${ }^{1}$, Dongmei Fu ${ }^{2}$ and Yuncai Wang ${ }^{3}$ \\ 1 College of Surveying and Geo-Informatics, Tongji University, Shanghai 200092, China; \\ caoxiangyang@tongji.edu.cn \\ 2 Real Estate Registration Center of Shanghai Municipal Planning and Land Resources Administration, \\ Shanghai 200003, China; dongmeifu90@163.com \\ 3 College of Architecture and Urban Planning, Tongji University, Shanghai 200092, China; \\ wyc1967@tongji.edu.cn \\ * Correspondence: shiyishao@tongji.edu.cn
}

Received: 16 May 2018; Accepted: 12 June 2018; Published: 15 June 2018

\begin{abstract}
The purpose of land consolidation is to promote moderately sized agricultural operations, intensive land use, concentrated population living and agglomerated industrial development. Previous research has primarily been macro- or mesoscale studies based on land ledger data, and analyzed only the effect of land consolidation on landscape ecological changes, only the resource and economic effects, or social effects or environmental effects of land consolidation. Aimed at addressing these shortcomings, an empirical analysis on the micro-scale based on land use patch data rather than land ledger data was conducted. Then, comprehensive research on land consolidation projects by integrating landscape pattern analysis with production, living, and ecological benefit assessments was performed. Furthermore, the relationship between land consolidation projects and the "Three Concentrations" policy was considered. The results show that: (1) land consolidation has directly or indirectly improved landscape ecological patterns of the project area; and (2) land consolidation has clearly improved the balanced distribution of cultivated land and the concentrated distribution of construction land in the project area. These changes not only improve the living conditions of farmers but also meet the construction requirements of the "Three Concentrations" in the Shanghai metropolitan suburbs.
\end{abstract}

Keywords: land consolidation; landscape pattern analysis; benefit evaluation; value discovery; Shanghai

\section{Introduction}

Land consolidation refers to the activities to improve the efficiency of land use on lands that are used inefficiently and unreasonably, or on lands that are unused or damaged from the production and construction behavior as well as natural disasters [1]. Land consolidation has been widely implemented in many countries. As a means of supporting land drainage and agricultural reclamation projects [2,3]; as a land management tool to address the problems of fragmentation and small-scale operations [4]; as an important tool to promote rural development [5]; as a new planning support system [6]; as a new spatial management system [7]; or as a new mode of governance in environmental policy [8], the cost and utility or performance and determining factors [9] of land consolidation are the focus of academic community.

The planned land consolidation activities in China began in the 1980s and have experienced three stage: preliminary exploration (1986-1997), continuous growth (1998-2007), and rapid development (2008-present). In Shanghai, from land consolidation dominated by "Three Concentrations" (that is, 
the farmland is concentrated in the hands of scale operators, the industry is concentrated in industrial parks, and the farmers' residences are transferred and concentrated to the towns) in the mid-1990s [10] to land consolidation guided by a new type of urbanization in the early 2000s [11] and to land consolidation oriented toward ecological civilization since 2013 [12-14], land consolidation has stepped into a new stage of comprehensive, systematic, universal and multiple-type synergetic development. By the end of 2015, Shanghai implemented eight municipal land consolidation projects and thirty-two projects that linked urban and rural construction land increases or decreases and oversaw the construction of seven country parks and the planning and construction of thirty-one street town suburban units. Twenty-two square kilometers of inefficient construction land has been reclaimed, 19,000 rural households have been relatively concentrated, and 193 square kilometers of ecological open space has been built in Shanghai.

For more than a century, land consolidation throughout the world has evolved from a simple agricultural development service to an urban and rural interaction with systematic and planned comprehensive governance activities. During this period, the tasks, methods, and measures of land consolidation have been continuously changing along with the requirements of social and economic development. Based on promoting the modernization of agriculture, land consolidation increasingly considers the coordination and sustainable development of population-land relations. In general, the main research progress of land consolidation is shown in the following aspects:

(1) The extension of connotation and change in role of land consolidation. Early land remediation goals were aimed at increasing agricultural productivity by consolidating scattered plots and adjusting field roads [3-5]. In The Netherlands, for example, at the end of the 19th century, reformist liberals argued for a legislative framework for the rational reallocation of land parcels to consolidate fragmented land holdings. In the early 20th century, land consolidation primarily promoted rural construction and agricultural self-sufficiency. Land consolidation was embraced as a means for supporting the agricultural sector by improving land drainage and bringing land into cultivation [3]. In the late 20th century, in addition to improving the production and operating conditions of agriculture and forestry and increasing agricultural output [15-17], land consolidation also acted as an instrument of rural planning, which shifted to the planning and design of landscape ecosystems, focusing on the protection of historical landscapes [18-26]. After entering the 21st century, land consolidation not only greatly improved its standards and scale but also focused on the integration of ecology, art, and humanities [27,28]. Meanwhile, the research scope of land remediation also broadens from rural areas to urban areas [29]. The main purpose of urban land remediation is to promote urban renewal. This shows that land consolidation has become a new tool to promote rural sustainable development [30] and urban sustainable development even the integration of urban-rural development.

(2) From the unilateral effect analysis to multiple effects evaluation of land remediation projects. The potential estimation and benefit evaluation is always the focus of land consolidation research. The former primarily regards counties and cities as study areas and involves the consolidation potential of cultivated land and agricultural land [31,32], the consolidation potential of rural residential areas [33], and the comprehensive consolidation potential of land [34,35]. However, there is less research on the potential of low-efficiency industrial land consolidation [36]. The latter aims to build an evaluation index system and to conduct comprehensive assessments to analyze the implementation effects of land consolidation projects. The overseas scholars primarily pay attention to the post-effect evaluation of project implementation, focusing on the empirical analysis of a project's economic, social, and environmental impacts [37-43]. In the selection of specific indicators, they primarily used alternative indicators that affect the conditions of agricultural production to evaluate the economic benefits of a project. For example, the selected indicators to assess the economic impact include the returns to farmers, the volume of public investment, farmland road transportation, the degree of land fragmentation, the degree of mechanization, land pattern or diseconomies derived from property fragmentation, increasing transportation costs, and lack of mechanization $[38,44]$. The selected 
indicators of social impact include changes in farmers' values, motivations and behavior, a personal and social conflict between innovation and values, and population density [38]. The selected indicators of environmental impact should cover important ecological, human welfare and sustainable concerns, specific include the effects of land consolidation on biodiversity, nature conservation and landscape improvement, energy and water resource use and management, land-use change, and the degree of response of administrations to ecological problems [29,38]. Johansen et al. proposed a novel indicator-based approach to assess the collective impact of multifunctional land consolidation to apply land consolidation for increasing the multifunctionality of the landscape. The index system they set up includes 25 specific indicators in five categories (farm economic indicators, environmental indicators, biodiversity conservation indicators, outdoor recreation indicators, and indicators for rural development) [44]. In recent years, evaluation of land consolidation process based on rural stakeholders [45] and assessment based on farmers' satisfaction [46] are gradually paid more attention, which shows that farmers' comprehensive welfare has become the focus of land remediation research.

Common benefit estimation methods include the Delphi method and questionnaire survey, AHP (Analytic Hierarchy Process), multi-factor comprehensive analysis methods [42,47,48], matter-element model [49,50] and Lewin behavior model [51]. Using the questionnaire method, for example, Li and Liu discussed the mechanism of farmers' participation in rural residential land consolidation and identified the factors affecting farmers' participation behavior based on rural residential land consolidation stages [52]. Overall, the performance evaluation of land consolidation projects has gradually expanded from focusing on behavioral outcomes to focusing on behavioral processes and behavioral outcomes [53-56].

(3) The study of land consolidation patterns and applicability is gaining more and more attention. This includes the pattern of rural residential area improvement [57-59], the pattern of low-efficiency industrial land consolidation [36], the pattern of country parks construction in the outskirts of metropolitan areas [60], the land consolidation pattern based on rural renewal [61], and the universal land remediation model [62]. In Shanghai, for instance, the first seven planned country parks will have an open ecological space of 130 square $\mathrm{km}$; the total planned area of 21 country parks in the city is about 400 square $\mathrm{km}$, which will become an important space carrier for Shanghai's ecological construction. Liu [63] generalized five typical models of land consolidation in Shanghai: multi-functional oriented agricultural land consolidation, urbanization-driven rural residential area improvement, village updating and rural residential area improvement, progressive industrial land consolidation, and landscape ecology-oriented land comprehensive consolidation, and summarized the features of each model. The patterns of land consolidation promoting poverty alleviation in poor areas has also been studied recently [64]. This demonstrates that land consolidation plays in poverty alleviation in poor areas, which supports the development of special industries, provides conditions for ecological migrants, builds infrastructure, increases employment and protects the ecological environment through guiding external inputs and exploring internal potentials.

To conclude, on the one hand, the current research on land consolidation primarily focuses on potential estimation, pattern recognition, and benefit evaluation, while less research focuses on spatial differentiation patterns and impacting mechanism. Past studies conducted a spatial analysis of landscape patterns [65]; evaluated the resource and economic effects; or social effects or environmental effects of land consolidation projects [66] but rarely combined the two. Moreover, the comprehensive values of land consolidation projects are seldom fully recognized. On the other hand, the data for land consolidation research, whether at the national scale [67], provincial scale [68] or county scale [69], were land accounting data or remote sensing image data, which do not easily meet the requirements of micro-analysis.

Compared with previous studies, our work is innovative in three aspects. First, an empirical analysis on the micro-scale based on land use patch data rather than land ledger data was conducted. Second, a comprehensive research on land consolidation projects by integrating landscape pattern analysis with production, living, and ecological benefit assessments was performed. Third, 
the relationship between land consolidation projects and the "Three Concentrations" policy to highlight the comprehensive value of the land consolidation projects was considered.

\section{Overview of the Study Area}

Two approved municipal land consolidation projects in China were selected for empirical analysis: one located in Heqing Town, Pudong New Area, and the other located in Langxia Town, Jinshan District, Shanghai (Figure 1). The former is located in an inner suburb of Shanghai with a project scale of 72.58 hectares and a total investment of approximately 128 million RMB. The project was initiated in June 2013 and was completed in June 2014. The construction period was 12 months. It was a project characterized by low-efficiency construction land reclamation. The latter was located in an outer suburb of Shanghai with a project scale of 1771.22 hectares and a total investment of approximately 710 million RMB. There were 2846 rural households in the region with a total population of 11,920 , and there was 1210.87 hectares of cultivated land. It was a project characterized by landscape ecological construction and high-standard farmland construction.

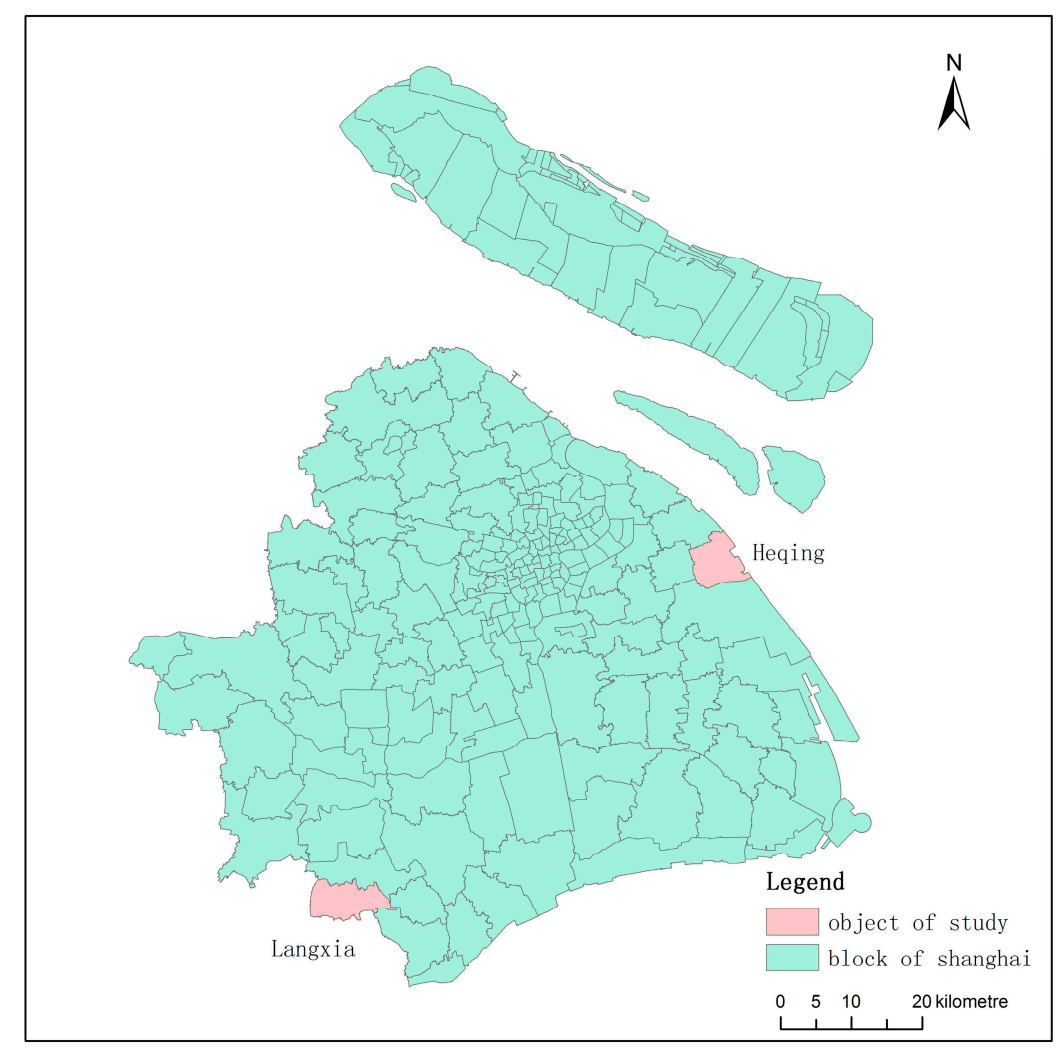

Figure 1. The location distribution of the sample study areas in Shanghai.

\section{Materials and Methods}

\subsection{Data Sources and Processing}

The data used in this article are land use type data of Heqing Town in the Pudong New Area and Langxia Town in the Jinshan District before and after land consolidation. First, the landscape types based on land use types were reclassified, which were divided into cultivated land, woodland, garden plot, construction land, water, traffic land and other. Second, all data into $4 \mathrm{~m} \times 4 \mathrm{~m}$ grids with classification information in ArcGIS 10.2 were rasterized (Esri, CA, USA). Third, landscape index analysis was performed using Fragstats 4.2 (Copyright 2013 Kevin Mcgarigal \& Eduard Ene). The results of the rasterization reclassification are shown in Figures 2-5. 

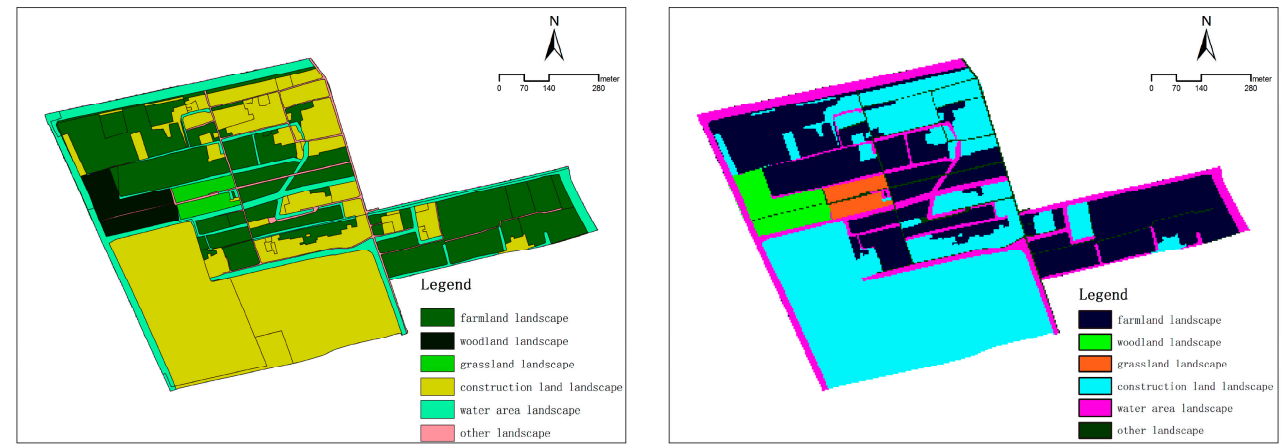

Figure 2. Rasterization reclassification scheme before land remediation in the project area of Heqing Town.
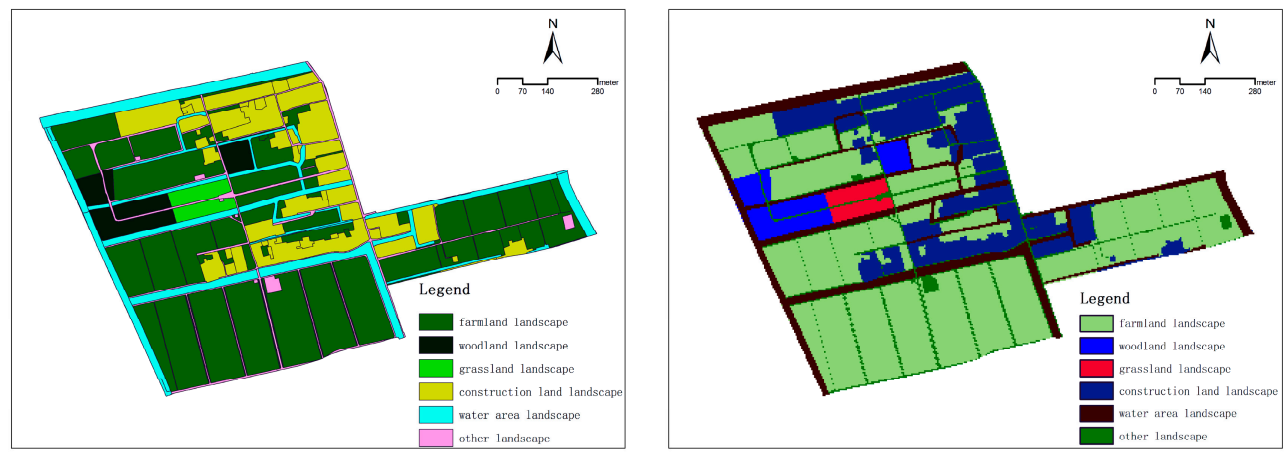

Figure 3. Rasterization reclassification scheme after land remediation in the project area of Heqing Town.
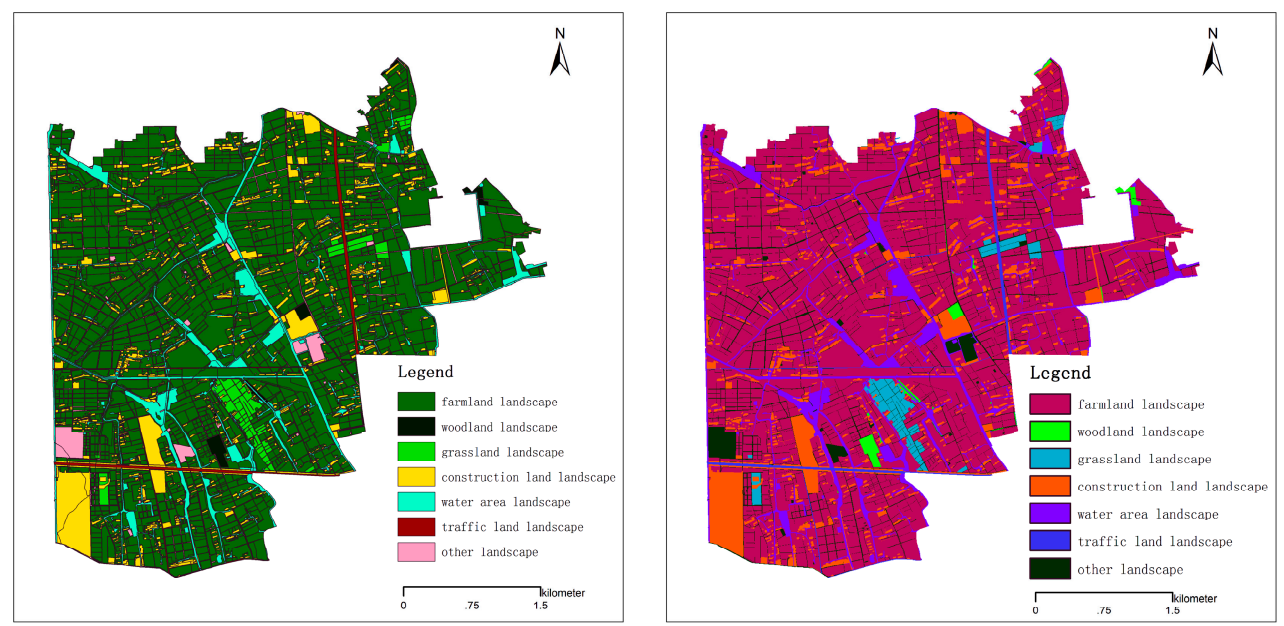

Figure 4. Rasterization reclassification scheme before land remediation in the project area of Langxia Town. 

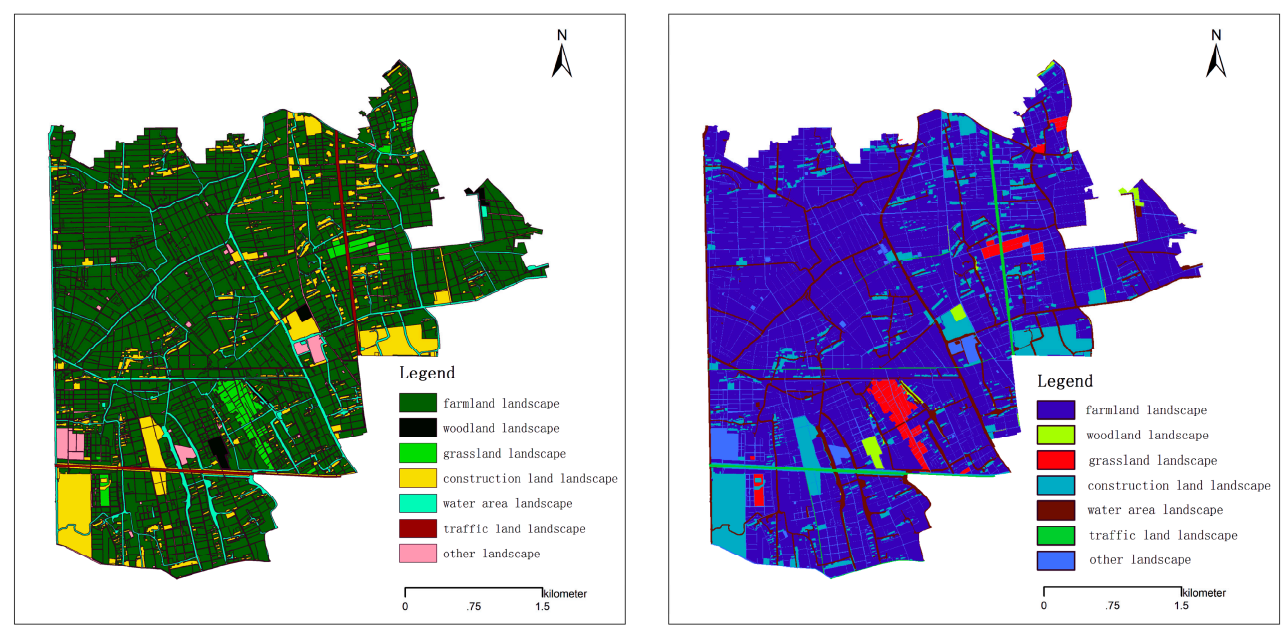

Figure 5. Rasterization reclassification scheme after land remediation in the project area of Langxia Town.

\subsection{Research Methods}

First, using Fragstats 4.2 software, based on the vector data of land consolidation patches for five years from 2011 to 2015 in Shanghai, the method of landscape pattern index analysis was used [70-72] to quantitatively evaluate the spatial variation effects of the abovementioned two project areas before and after land remediation. Second, by constructing an evaluation index system, a comprehensive benefit evaluation method was used to quantitatively estimate the dynamic changes in the production, life and ecological benefits of the two project areas.

\subsubsection{Landscape Pattern Index Analysis}

First, in the Fragstats 4.2 software, the class area (CA), number of patches (NP), patch density (PD), mean patch size (MPS) and mean patch fractal dimension (FRAC_MN) were calculated to evaluate the changes in the spatial patterns of different landscape types before and after land remediation. Second, the patch shape index (PSI), contagion index (CONTAG), Shannon's diversity index (SHDI), landscape fragmentation (FS), aggregation index (AI), and connectance index (CI) were calculated to analyze the effect of land consolidation on the overall patch landscape pattern in the two project areas. Several important formulas for calculating the landscape pattern index are shown in Table 1.

Table 1. Several indexes of landscape pattern analysis.

\begin{tabular}{|c|c|c|c|}
\hline Index & Calculation Formula & Meaning & Unit \\
\hline Patch shape index & $P S I=\frac{P_{i j}}{2 \sqrt{\pi a_{i j}}}$ & $\begin{array}{l}P_{i j} \text { is the perimeter of the patch, } a_{i j} \text { is the patch } \\
\text { area. The smaller the } S I \text {, the more regular and } \\
\text { simple the shape of the patch; the larger the } \\
P S I \text {, the more complex the shape of the patch. }\end{array}$ & / \\
\hline Contagion index & $\begin{array}{c}\text { CONTAG }= \\
{\left[1+\frac{\sum_{i=1}^{m} \sum_{k=1}^{m}\left[\left(P_{i}\right)\left(\frac{g_{i k}}{\sum_{k=1}^{m} g_{i k}}\right)\right]\left[\ln \left(P_{i}\right)\left(\frac{g_{i k}}{\sum_{k=1}^{m} g_{i k}}\right)\right]}{2 \ln (m)}\right] *} \\
100\end{array}$ & $\begin{array}{l}P_{i} \text { is the percentage of area occupied by type(i) } \\
\text { patches; } g_{i k} \text { is the number of type(i) patches } \\
\text { and type }(\mathrm{K}) \text { patches adjacent to each other; } \mathrm{m} \\
\text { is the total number of patch types; the range of } \\
\text { CONTAG: }(0,100) \text {. }\end{array}$ & $\%$ \\
\hline $\begin{array}{l}\text { Shannon's diversity } \\
\text { index }\end{array}$ & $S H D I=-\sum_{i=1}^{n} P_{i} \ln \left(P_{i}\right)$ & $\begin{array}{l}P_{i} \text { is the proportion of landscape type } i \text { to the } \\
\text { total area; } n \text { is the total number of landscape } \\
\text { types in the study area. }\end{array}$ & / \\
\hline $\begin{array}{l}\text { Landscape } \\
\text { fragmentation } \\
\text { index * }\end{array}$ & $\begin{aligned} F S=1-\frac{1}{A S I}, A S I & =\sum_{i=1}^{n}\left(\frac{A_{i} * S I_{i}}{A}\right), S I_{i}=\frac{P_{i}}{4 \sqrt{A_{i}}}, \\
A & =\sum_{i=1}^{n} A_{i}\end{aligned}$ & $\begin{array}{l}\text { ASI is area-weighted average shape } \\
\text { fragmentation index, } S I_{i} \text { is the shape index of } \\
\text { landscape patch(i), } P_{i} \text { is the perimeter of } \\
\text { landscape patch(i); } \mathrm{A} \text { is the area of landscape } \\
\text { patch(i); } A \text { is the landscape area, and } n \text { is the } \\
\text { number of landscape patches. }\end{array}$ & / \\
\hline
\end{tabular}


Table 1. Cont.

\begin{tabular}{|c|c|c|c|}
\hline Index & Calculation Formula & Meaning & Unit \\
\hline Aggregation index & $A I=\left[\sum_{i=1}^{m}\left(\frac{g_{i i}}{\max \rightarrow g_{i i}}\right) P_{i}\right] * 100$ & $\begin{array}{l}g_{i i} \text { is the number of similar and neighboring } \\
\text { patches of the corresponding landscape type; } \\
\text { the range of } A I:[0,100] \text {; the larger the value, } \\
\text { the higher the same or similar patch } \\
\text { aggregation in the landscape. }\end{array}$ & $\%$ \\
\hline Connectance index & $C I=\left[\frac{\sum_{j \neq k}^{n} C_{i j k}}{\frac{n_{i}\left(n_{i}-1\right)}{2}}\right] * 100$ & $\begin{array}{l}C_{i j k} \text { is the joining between patch } \mathrm{j} \text { and } \mathrm{k}(0= \\
\text { unjoined, } 1=\text { joined) of the corresponding } \\
\text { patch type }(\mathrm{i}) \text {, based on a user specified } \\
\text { threshold distance; } n_{i} \text { is the number of patches } \\
\text { in the landscape of the corresponding patch } \\
\text { type (class). }\end{array}$ & $\%$ \\
\hline
\end{tabular}

Note: landscape fragmentation index uses area-weighted average shape fragmentation index to measure.

\subsubsection{Method of Benefit Evaluation for Land Consolidation}

(1) Selection of evaluation indicators: The index system method was applied to assess the comprehensive benefit of land consolidation. On the one hand, the evaluation indicators were selected according to the goals of the land consolidation and the social development background in the evaluation area; on the other hand, different consolidation objects directly led to differences in the selection of evaluation indicators. In this study, the land consolidation project in Heqing Town focuses on the pursuit of beautiful countryside construction through the combination of construction land reclamation with ecological landscape land consolidation, while the project in Langxia Town focuses on the construction of landscape ecology and high-standard farmland. To abide by the principles of following local conditions, combining qualitative and quantitative data, connecting systems, maintaining flexibility, and the unification of consolidation appeal, completion processes and follow-up operations, we constructed the following evaluation index system from three aspects: production, living and ecological benefits (Table 2).

Table 2. The index system of benefits evaluation for land consolidation projects.

\begin{tabular}{|c|c|c|c|}
\hline Target Layer & Criteria Layer & Indicator Layer & Computational Formula \\
\hline \multirow{9}{*}{$\begin{array}{l}\text { Comprehensive } \\
\text { benefits of land } \\
\text { consolidation } \\
\text { projects }\end{array}$} & \multirow{3}{*}{$\begin{array}{l}\text { Production } \\
\text { benefits }\end{array}$} & $\begin{array}{l}\text { Increase rate of cultivated } \\
\text { land }\left(C_{1}\right)\end{array}$ & $\begin{array}{l}C_{1}=(\text { New cultivated land area/area of project region }) \\
* 100 \%\end{array}$ \\
\hline & & $\begin{array}{l}\text { The improvement of road } \\
\text { network }\left(C_{2}\right)\end{array}$ & $\begin{array}{l}\mathrm{C}_{2}=\text { The length of improved road network/area of } \\
\text { project region }\end{array}$ \\
\hline & & $\begin{array}{l}\text { Change rate of gross } \\
\text { agricultural output value } \\
\left(C_{3}\right)\end{array}$ & $\begin{array}{l}C_{3}=(\text { Gross agricultural output value after } \\
\text { remediation }- \text { gross agricultural output value before } \\
\text { remediation } / \text { area of project region }\end{array}$ \\
\hline & \multirow{3}{*}{ Living benefits } & $\begin{array}{l}\text { Resettlement rate of } \\
\text { relocation population }\left(\mathrm{C}_{4}\right)\end{array}$ & $\begin{array}{l}C_{4}=(\text { Relocation population/population of project } \\
\text { region }) * 100 \%\end{array}$ \\
\hline & & $\begin{array}{l}\text { Change rate of public land } \\
\left(\mathrm{C}_{5}\right)\end{array}$ & $\begin{array}{l}C_{5}=(\text { Area of public land after renovation }- \text { area of } \\
\text { public land before renovation }) / \text { area of project region * } \\
100 \%\end{array}$ \\
\hline & & $\begin{array}{l}\text { Proportion of new } \\
\text { resettlement area }\left(\mathrm{C}_{6}\right)\end{array}$ & $\begin{array}{l}C_{6}=(\text { Area of the new settlement area/total area of the } \\
\text { residential site in the project area }) * 100 \%\end{array}$ \\
\hline & \multirow{3}{*}{$\begin{array}{l}\text { Ecological } \\
\text { benefits }\end{array}$} & $\begin{array}{l}\text { Saving rate of construction } \\
\text { land }\left(C_{7}\right)\end{array}$ & $\begin{array}{l}C_{7}=(\text { Area of construction land before renovation - } \\
\text { area of construction land after renovation)/area of } \\
\text { construction land before renovation * } 100 \%\end{array}$ \\
\hline & & $\begin{array}{l}\text { Change rate of ecological } \\
\text { land area }\left(C_{8}\right)\end{array}$ & $\begin{array}{l}C_{8}=(\text { Area of ecological land after renovation }- \text { area } \\
\text { of ecological land before renovation }) / \text { area of } \\
\text { ecological land before renovation * } 100 \%\end{array}$ \\
\hline & & $\begin{array}{l}\text { The improvement of water } \\
\text { network }\left(C_{9}\right)\end{array}$ & $\begin{array}{l}C_{9}=\text { Regulation of water network length/area of } \\
\text { project region }\end{array}$ \\
\hline
\end{tabular}

The important reasons for selecting the above indicators are as follows: (1) In terms of the production benefits, the increase in cultivated land can carry more demand for agricultural production, the improvement of infrastructure such as roads can greatly facilitate agricultural production, and the increase in agricultural output value relates to whether land consolidation can boost the 
agricultural-scale management; (2) In terms of the living benefits, municipal land remediation projects usually replace the homesteads of peasant households with the commercial housing of the town. In the process of replacement, farmers have generally improved their housing conditions, and the growth in public land directly benefits the living conditions of farmers in the project area. Before the consolidation project is launched, the houses in the project area are mostly obsolete, and infrastructure facilities are generally deficient; (3) In terms of the ecological benefits, one of the focuses of intensive land use is the rational distribution and utilization of construction land. The increase in ecological land plays an important role in the regional ecological environment, and the renovation of the water network in the project area plays an important role in regulating water storage and in improving agricultural production efficiency.

(2) Determination of indicator weights: The analytic hierarchy process (AHP) is used to determine the relative weight of each indicator. This method was proposed by Thomas L. Saaty, a US operations researcher, in the 1970s, which is an analysis method of combination of qualitative and quantitative [73]. The AHP is a multi-objective, multi-criteria, multi-factor and multi-level decision-making method that uses hierarchical structures to represent a problem [74]. The basic principle of this method is: If there is a group of objects, how should their weights be determined without weighing apparatus? First, calculate the mutual weight between any two, constituting a judgment matrix, and then obtain the matrix maximum eigenvalue and its corresponding eigenvector [75]. This eigenvector is the mutual weight of the set of objects, and it refers to the relative weight in this article. For example, there is a group of objects. $A_{1}, A_{2}, \cdots A_{n}$, whose weights are denoted as $W_{1}, W_{2}, \cdots, W_{n}$, respectively. Calculating the mutual weight between any two and construct a judgment matrix:

$$
\mathrm{A}=\left(\begin{array}{ccc}
W_{1} / W_{2} & \cdots & W_{1} / W_{n} \\
\vdots & \ddots & \vdots \\
W_{n} / W_{1} & \cdots & W_{n} / W_{n}
\end{array}\right)
$$

If the weight vector is written as $\mathrm{W}=\left(\mathrm{W}_{1}, \mathrm{~W}_{2}, \cdots, \mathrm{W}_{n}\right)^{T}$, then $\mathrm{AW}=\lambda \max \cdot \mathrm{W}$.

$\mathrm{W}$ is the eigenvector of the judgment matrix $\mathrm{A}, \lambda \max$ is the maximum eigenvalue of the matrix $\mathrm{A}$, and $\mathrm{W}$ is the relative weight of the objects. The main steps are shown in Figure 6. The weights of the evaluation indicators are obtained in Table 3.

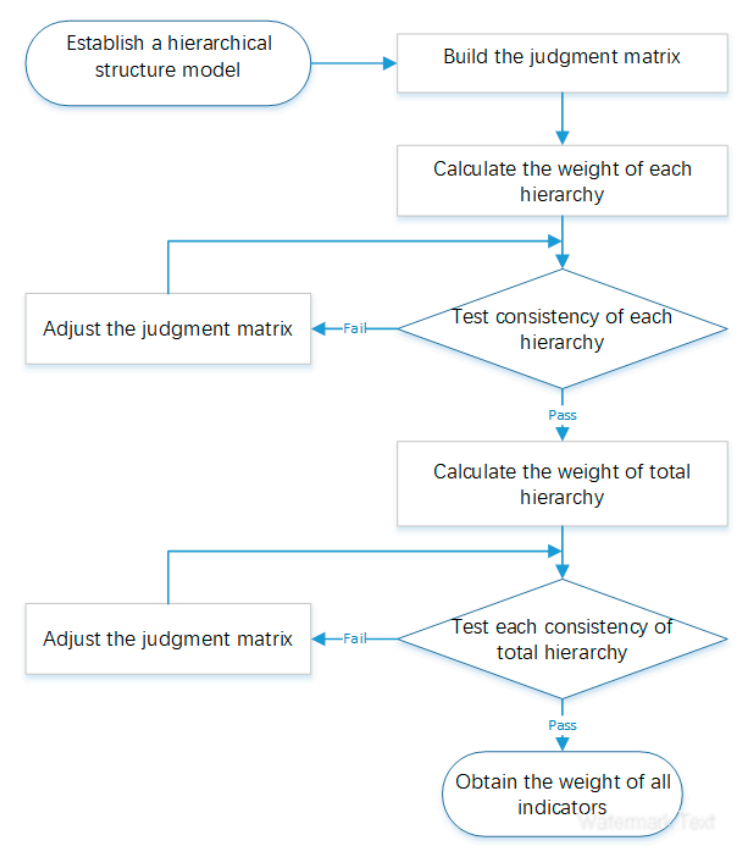

Figure 6. Main steps of AHP. 
Table 3. Weight of evaluation indicators.

\begin{tabular}{|c|c|c|c|c|c|}
\hline Target Layer & $\begin{array}{c}\text { Criteria } \\
\text { Layer }\end{array}$ & Indicator Layer & $\begin{array}{c}\text { Relative } \\
\text { Weight }\end{array}$ & $\begin{array}{l}\text { Comprehensive } \\
\text { Weight }\end{array}$ & Rank \\
\hline \multirow{8}{*}{$\begin{array}{l}\text { Comprehensive } \\
\text { benefits of land } \\
\text { consolidation } \\
\text { projects }\end{array}$} & \multirow{3}{*}{$\begin{array}{l}\text { Production } \\
\text { benefits } \\
0.2808\end{array}$} & Increase rate of cultivated land & 0.1047 & 0.0294 & 8 \\
\hline & & $\begin{array}{l}\text { The improvement of road } \\
\text { network }\end{array}$ & 0.2583 & 0.0725 & 6 \\
\hline & & $\begin{array}{l}\text { Change rate of gross } \\
\text { agricultural output value }\end{array}$ & 0.6370 & 0.1789 & 3 \\
\hline & \multirow{3}{*}{$\begin{array}{l}\text { Living } \\
\text { benefits } \\
0.1350\end{array}$} & $\begin{array}{l}\text { Resettlement rate of relocation } \\
\text { population }\end{array}$ & 0.2583 & 0.0349 & 7 \\
\hline & & Change rate of public land & 0.6370 & 0.0860 & 5 \\
\hline & & $\begin{array}{l}\text { Proportion of new } \\
\text { resettlement area }\end{array}$ & 0.1047 & 0.0141 & 9 \\
\hline & \multirow{2}{*}{$\begin{array}{l}\text { Ecological } \\
\text { benefits } \\
0.5842\end{array}$} & $\begin{array}{l}\text { Saving rate of construction } \\
\text { land }\end{array}$ & 0.2211 & 0.1292 & 4 \\
\hline & & $\begin{array}{l}\text { Change rate of ecological land } \\
\text { area }\end{array}$ & 0.3189 & 0.1863 & 2 \\
\hline & & $\begin{array}{l}\text { The improvement of water } \\
\text { network }\end{array}$ & 0.4600 & 0.2687 & 1 \\
\hline
\end{tabular}

Notes: (1) The relative weight is the weight value of the importance of each element associated with it in the same layer for an element in the upper layer; (2) The comprehensive weight means that the highest layer (Target layer) has the weight value of the lowest layer (Indicator layer); (3) The rank is the order of importance of comprehensive weights. Rank 1 indicates that the indicator has the largest comprehensive weight, which has the greatest impact on the target, and so on.

\section{Analysis of Results}

\subsection{Impact of Land Consolidation on Landscape Patterns}

(1) Changes in the patch shape index

The patch shape index is often used to indicate the degree of patch development and the complexity of the patch boundary. As can be seen in Table 4, after land consolidation, the PSI of Heqing Town fell from 1.3950 to 1.3413, and the PSI of Langxia Town decreased from 1.4401 to 1.3236. These phenomena show that, after land remediation, the shapes of the two towns' patches changed from irregular to regular, and the landscape changed from cluttered to simple.

Table 4. Comparison of main landscape pattern indicators before and after land consolidation.

\begin{tabular}{cccccccc}
\hline \multirow{2}{*}{ Region } & Time & $\begin{array}{c}\text { Patch } \\
\text { Shape } \\
\text { Index }\end{array}$ & $\begin{array}{c}\text { Contagion } \\
\text { Index }\end{array}$ & $\begin{array}{c}\text { Shannon's } \\
\text { Diversity } \\
\text { Index }\end{array}$ & $\begin{array}{c}\text { Landscape } \\
\text { Fragmentation }\end{array}$ & $\begin{array}{c}\text { Aggregation } \\
\text { Index }\end{array}$ & $\begin{array}{c}\text { Connectance } \\
\text { Index }\end{array}$ \\
\cline { 3 - 8 } & & PSI & CONTAG & SHDI & FS & AI & CI \\
\hline Heqing & Before & 1.3950 & 62.2806 & 1.3648 & 0.5497 & 0.9903 & 95.9646 \\
Town & After & 1.3413 & 60.8552 & 1.3859 & 0.5953 & 0.5257 & 94.7005 \\
\hline Langxia & Before & 1.4401 & 59.7023 & 1.5452 & 0.7763 & 0.0328 & 94.5889 \\
Town & After & 1.3236 & 60.2907 & 1.5254 & 0.7550 & 0.0199 & 94.6124 \\
\hline
\end{tabular}

Note: (1) In Heqing Town, the time-point before the consolidation was June 2013, and the time-point after the consolidation was June 2014; (2) In Langxia Town, the time-point before consolidation was January 2012, and the time-point after consolidation was December 2014; (3) When calculating the Connectance Index, we set the threshold distance for the connectivity of habitat patches in landscape types is $10 \mathrm{~m}$.

(2) Changes in the contagion index

The contagion index (CONTAG) is primarily used to characterize the degree of agglomeration or extension of different types of landscape patches. It is one of the most important indexes to describe the landscape pattern [71]. A high degree of aggregation indicates that the dominant patches in the landscape have good splicing. In contrast, a low degree of aggregation indicates that the landscape has a high degree of fragmentation. The CONTAG of Heqing Town decreased from 62.2806 to 60.8552, which indicates that the isolated patches increased after land consolidation. The CONTAG of Langxia 
Town increased from 59.7023 to 60.2907 , which indicates that the number of isolated patches reduced after land consolidation, and the splicing of the dominant patch types improved accordingly, which was more conducive to the scale management of cultivated land.

(3) Changes in the landscape diversity index

Landscape diversity is represented by the Shannon's diversity index (SHDI). SHDI reflects the number of landscape components and the uniformity of the proportions of the components within the landscape. In a landscape system, a high value of SHDI indicates that the land use is richer, the degree of fragmentation is higher, and the content of uncertain information is also greater. As shown in Table 4, SHDI in Heqing Town increased from 1.3648 to 1.3859, which indicates that the degree of land use fragmentation has increased. SHDI in Langxia Town fell from 1.5452 to 1.5254, which indicates that the degree of land use fragmentation decreased after land consolidation.

(4) Changes in the degree of landscape fragmentation

The degree of landscape fragmentation (FS) primarily refers to the degree of fragmentation of the landscape, which reflects the complexity of the spatial structure of the landscape and to some extent reflects the degree of human disturbance to the landscape [71,76-79]. The FS in Langxia Town decreased from 0.7763 to 0.7550 , indicating that, after land consolidation, Langxia Town not only reduced idle construction land but also that the layout of rural settlement became more concentrated.

(5) Changes in the aggregation index

The aggregation index (AI) refers to the degree of aggregation of the same or similar patches in the landscape. A high value of the AI means that the landscape is composed of several reunited large patches; in contrast, a low AI means that the landscape consists of many small patches. The AI of Heqing Town decreased from 0.9903 to 0.5257 , and the AI of Langxia Town decreased from 0.0328 to 0.0199 , which shows that the distribution of patches was more even and the concentration degree was weakened after land consolidation. Especially in Langxia Town, the agglomeration effect of farmland in the project area was reduced, and the cultivated land was more evenly distributed. The even distribution of farmland made it easier for farmers to engage in agricultural production.

(6) Changes in the connectance index

The connectance index (CI) equals the number of functional connections between all patches of the corresponding patch type divided by the total number of possible connections between all patches of the corresponding patch type multiplied by 100 [80-84]. The CI of Heqing Town slightly decreased from 95.9646 to 94.7005 , and the CI of Langxia Town slightly increased from 94.5889 to 94.6124. These show that, although the CI changed, it did not change much. The CI was close to 100 , indicating that both habitat patches had good connectivity.

\subsection{Comprehensive Benefit Evaluation of Land Remediation}

As can be seen in Tables 3 and 5: (1) The comprehensive weights of the three indicators in the ecological benefits are relatively high, which is in line with the interests of the land remediation of Shanghai. The improvement of the water network has a great impact on the ecological benefits. The length of improved water network is $6.5 \mathrm{~km}$ in Heqing project area and $49.98 \mathrm{~km}$ in Langxia project area. The change from a stinking ditch to a clear water pool has greatly improved the ecological benefits of the remediation area. At the same time, the ecological land area of Heqing project area increased from 39.33 ha to 61.41 ha, that of Langxia project area increased from 101.74 ha to 103.23 ha; (2) The comprehensive weights of the three indicators in the production efficiency rank second, which indicates that whether it is the rehabilitation of agricultural land or the rehabilitation of inefficient construction land, higher agricultural efficiency, farmers' income increase, and rural value-added are still important goals for land consolidation. For instance, after land remediation, the total agricultural output value of Heqing project area increased from 92.61 million RMB to 96.09 million RMB, and that of Langxia project area increased from 325 million RMB to 380 million RMB; (3) The comprehensive weights of the three indicators on the living efficiency are ranked last. There are three main reasons: the original rural infrastructure is good, farmers' houses have been relatively concentrated, and land remediation 
primarily affects the living benefits of farmers through the improvement of the external environment. For example, after land remediation, public land area of Heqing project area increased from 93.87 ha to 93.96 ha, and that of Langxia project area increased from 26.76 ha to 81.85 ha. Meanwhile, it does not involve the relocation of population and the construction of new settlement area in Heqing project area.

Table 5. The specific values of all indicators of Heqing Town and Langxia Town.

\begin{tabular}{cccc}
\hline Indicators & Heqing Town & Langxia Town & Unit \\
\hline Increase rate of cultivated land & 24.36 & 3.16 & $\%$ \\
The improvement of road network & 0.13 & 0.11 & $\mathrm{Km} / \mathrm{ha}$ \\
Change rate of gross agricultural output value & 4.60 & 3.10 & 10 thousand yuan/ha \\
Resettlement rate of relocation population & 0 & 22.47 & $\%$ \\
Change rate of public land & 0.12 & 3.11 & $\%$ \\
Proportion of new resettlement area & 0 & 25.36 & $\%$ \\
Saving rate of construction land & 66.41 & 13.84 & $\%$ \\
Change rate of ecological land area & 56.16 & 1.46 & $\mathrm{Km} / \mathrm{ha}$ \\
The improvement of water network & 0.08 & 0.02 & \\
\hline
\end{tabular}

\subsection{The Comprehensive Value of Land Consolidation Projects}

Why does Shanghai City Government want to carry out land consolidation in the suburbs of the Shanghai metropolis? What is the comprehensive value of land consolidation?

(1) Land consolidation and the value of the increase and centralized management of cultivated land

Urban sprawl and the reduction of farmland are common phenomena in the process of global urbanization. However, land consolidation is likely to end or even reverse this trend. Through the implementation of land remediation, the area of cultivated land has increased, including the increases of 18.37 hectares in Heqing Town and 55.9 hectares in Langxia Town. This relieves the shrinkage and degradation of cultivated land in Shanghai metropolitan suburbs. Meanwhile, the number and density of cultivated patches has also increased (Tables 6 and 7), and its distribution is more homogenized. This will make the agricultural scale operation more convenient.

Table 6. Change in the landscape pattern before and after land consolidation in Heqing Town.

\begin{tabular}{|c|c|c|c|c|c|c|}
\hline \multirow{2}{*}{ Land Type } & \multirow{2}{*}{ Time } & Class Area & Number of Patches & Patch Density & Mean Patch Size & $\begin{array}{l}\text { Mean Patch Fractal } \\
\text { Dimension }\end{array}$ \\
\hline & & CA (ha) & NP & PD (No./100 ha) & MPS (ha) & FRAC_MN \\
\hline \multirow{2}{*}{ Cultivated land } & Before & 24.0560 & 38 & 26.0245 & 0.6331 & 1.0759 \\
\hline & After & 38.9024 & 56 & 38.3520 & 0.6947 & 1.0950 \\
\hline \multirow{2}{*}{ Garden plot } & Before & 1.3680 & 2 & 1.3697 & 0.6840 & 1.1060 \\
\hline & After & 1.3712 & 2 & 1.3697 & 0.6856 & 1.1024 \\
\hline \multirow[b]{2}{*}{ Woodland } & Before & 2.7040 & 11 & 7.5334 & 0.2458 & 1.0127 \\
\hline & After & 3.2960 & 12 & 8.2183 & 0.2747 & 1.0282 \\
\hline \multirow[b]{2}{*}{ Construction land } & Before & 33.2272 & 28 & 19.1760 & 1.1867 & 1.0836 \\
\hline & After & 13.8800 & 22 & 15.0668 & 0.6309 & 1.0780 \\
\hline \multirow{2}{*}{ Water } & Before & 9.4432 & 19 & 13.0123 & 0.4970 & 1.2306 \\
\hline & After & 10.6080 & 10 & 6.8486 & 1.0608 & 1.3237 \\
\hline \multirow{2}{*}{ Other } & Before & 1.7776 & 165 & 113.0013 & 0.0108 & 1.0813 \\
\hline & After & 4.5184 & 324 & 221.8935 & 0.0139 & 1.0809 \\
\hline
\end{tabular}

Note: In Heqing Town, the time-point before land consolidation was June 2013, and the time-point after land consolidation was June 2014. 
Table 7. Change in the landscape pattern before and after land consolidation in Langxia Town.

\begin{tabular}{ccccccc}
\hline \multirow{2}{*}{ Land Type } & Time & Class Area & Number of Patches & Patch Density & Mean Patch Size & $\begin{array}{c}\text { Mean Patch Fractal } \\
\text { Dimension }\end{array}$ \\
\cline { 2 - 7 } & & CA (ha) & NP & PD (No./100 ha) & MPS (ha) & FRAC_MN \\
\hline \multirow{2}{*}{ Cultivated land } & Before & 1257.8432 & 320 & 10.3329 & 3.9308 & 1.1370 \\
& After & 1285.1824 & 466 & 15.0472 & 2.7579 & 1.1242 \\
\hline \multirow{2}{*}{ Garden plot } & Before & 33.9648 & 15 & 0.4844 & 2.2643 & 1.1291 \\
& After & 33.1072 & 24 & 0.7750 & 1.3795 & 1.1530 \\
\hline \multirow{2}{*}{ Woodland } & Before & 10.9248 & 28 & 0.9364 & 0.3767 & 1.1692 \\
& After & 10.4784 & 40 & 1.2916 & 0.2620 & 1.1627 \\
\hline \multirow{2}{*}{ Construction land } & Before & 179.0064 & 1076 & 34.7443 & 0.1664 & 1.0903 \\
& After & 172.4080 & 856 & 27.6404 & 0.2014 & 1.0907 \\
\hline \multirow{2}{*}{ Water } & Before & 154.1440 & 324 & 10.4620 & 0.4758 & 1.1506 \\
& After & 137.5696 & 213 & 6.8778 & 0.6459 & 1.1435 \\
\hline \multirow{2}{*}{ Traffic land } & Before & 19.1152 & 27 & 0.8718 & 0.7080 & 1.1234 \\
& After & 19.0944 & 29 & 0.9364 & 0.6584 & 1.1226 \\
\hline \multirow{2}{*}{ Other } & Before & 116.2208 & 4836 & 156.1556 & 0.0240 & 1.0979 \\
& After & 113.3792 & 7002 & 226.0962 & 0.0162 & 1.0765 \\
\hline
\end{tabular}

Note: In Langxia Town, the time-point before land consolidation was January 2012, and the time-point after land consolidation was December 2014.

(2) Land consolidation and the value of the reduction and centralization of construction land

By implementing land consolidation, the scattered distribution pattern of rural industrial land and residential sites has shown a marked improvement. On the one hand, it promotes the reduction of low-efficiency construction land and provides an opportunity for industrial restructuring, land replacement, and residential concentration. For example, the area of low-efficiency construction land in the Heqing project area has been reduced by 19.3472 hectares (Table 6); in Langxia Town, the construction land area has been reduced by 6.5984 hectares, the number of patches has been reduced by 220 , and the mean patch size has been expanded by 0.045 hectares (Table 7), which indicates that rural industrial land and residential land tend to be more concentrated. On the other hand, the implementation of land consolidation can not only guide the integration of agriculture and the secondary and tertiary industries but also promote the mixed utilization of rural land, raise agricultural efficiency, and increase farmers' income. For example, farmland can be used for leisurely agriculture, rural tourism, agricultural education, agricultural science and farming experience, and other functions, and the rural collective construction land can be used for the home-stay facility folk and creative leisure.

(3) Land consolidation and the value of the network of ecological landscape patterns

The implementation of land consolidation leads to several ecological advantages. First, the trend of farmland fragmentation has been suppressed. Second, rivers are dredged, water systems are connected, and the water quality is improved. Third, through ecological landscape design, forest network construction is carried out in the consolidation area, the regional microclimate is improved and biodiversity is enriched.

(4) Land consolidation and the value of the reconstruction of rural culture

On the one hand, by implementing land consolidation guided by ecological sightseeing agriculture, the cultural value of regional high-quality agricultural products has recovered, high-standard farmland has been constructed, and the natural rural landscape has been preserved. Rural recreational space has been expanded, and the revival of rural areas has been promoted. On the other hand, local characteristics have been further excavated and displayed, and the overall rural conditions such as fields, water, roads, forests, and villages have been improved. Taking rural garden culture as the cultural standard, land consolidation helped to protect the natural environment of the villages, implement green village construction and courtyard project construction, combine landscape design with humanistic arts, and reshape the value of rural culture. For example, the Langxia country park is not only a place for local people to live and work, but also a country space for urban visitors to relax. 


\section{Conclusions and Discussion}

Land consolidation in the Shanghai metropolitan area is a systematic project with multiple influences. It not only has significant impacts on soil quality, the hydrological environment, biodiversity, and farmland microclimates but also involves the direct or indirect conversion of land use patterns such as plot size, shape and distance, consequently, saving time and reducing production costs. It also has profound impacts on the increase of cultivated land area, crop yield per unit area and farmers' income, and the improvement of agricultural production conditions of the project area. Furthermore, in a wider context, land consolidation is an important tool to promote rural sustainable development by means of improving rural infrastructure and public facilities, housing conditions and the protection of natural resources, the dynamic integration of green development, green living and green ecology has been achieved in rural areas.

The empirical analysis of the above two projects shows that land consolidation has obviously improved the distribution of cultivated land and the distribution of concentrated construction land. The former promotes the convenience of agricultural production in the project area, while the latter releases the occupied space and effectively increases the area of cultivated land and ecological space. These changes not only improve the living conditions of farmers and optimize the ecological environment in the suburbs and rural areas, but also transfer the land for industrial upgrading and meet the construction requirements of the "Three Concentrations" in Shanghai metropolitan suburbs.

The locational difference determines the difference in land consolidation goals and effects. Heqing Town is located in an inner suburb of Shanghai, and Langxia Town is located in an outer suburb of Shanghai. The former assumes the responsibility of coordinating the contradictions among ecological leisure, cultivated land protection and urban expansion in the Shanghai metropolis, aiming to achieve integration of production functions, ecological functions and leisure functions. The latter regards characteristic agriculture and new rural construction as its mission, aiming to promote a moderately sized agricultural operation, intensive land use, concentrated population living and agglomerated industrial development. Because different land consolidation projects have different goals, the advantages and disadvantages of their rectification effects cannot be directly compared. It is also not appropriate to judge the quality of various models intuitively. Therefore, in the evaluation of the comprehensive benefits of land consolidation projects, this paper only quantitatively assesses the importance of various impacting factors.

In comprehensive benefits evaluation of land remediation projects, the ecological benefit is the first, the productive benefit is the second and the life benefit is the third. This result accords with the reality of land remediation in Shanghai. The scarcity of ecological resources and the fragmentation of ecological network are the main constraints of Shanghai's future development. The important areas and projects of land consolidation in Shanghai are located in the main ecological corridors, aimed to address this key restrictive factor. Shanghai is now building an ecological space network system that focuses on water, integrates water resources, green resources and cultural resources, and merges green land, woodland, garden plot, cultivated land, water and tidal flats. However, in the Langxia Town, most of the original aquaculture water surface, rivers and ponds were converted into cultivated land in the last few years. This phenomenon must be corrected or reversed, as water areas cannot be easily converted into arable land or construction land. The ecological functions and values of water resources should be fully understood and the characteristics of the Jiangnan Water Township should be strictly protected.

In China, previous studies analyzed only the effect of land consolidation on landscape ecological changes [65,72]; only the resource and economic profits [2]; or social effects [66] or ecological benefit [85] of land consolidation (projects). Few research achievements have been made in comprehensive benefits evaluation of land remediation. However, most of single effect evaluation usually include the comprehensive effect evaluation such as economy, society and environment [66,85]. Overseas, a few scholars have estimated the effects of land consolidation (projects) including economic, social and environmental impacts [86-89] with the help of econometric models and methods. In the present 
study, an empirical analysis at the micro-scale based on land use patch data rather than land ledger data was conducted. Then, comprehensive research on land consolidation projects by integrating landscape pattern analysis with production, living, and ecological benefit assessments was performed. Furthermore, the relationship between land consolidation projects and the "Three Concentrations" policy was considered, broadening the perspective of this type of research.

Author Contributions: All authors contributed to the work in this paper. Y.S., X.C. and Y.W. designed the research and wrote the paper. X.C. and D.F. participated in the creation of the graphics.

Funding: This paper was funded by the project for China National R \& D Program entitled "Building strong ecological security patterns through elevating green infrastructure's level of ecosystem service" (No. 2017YFC0505705) and the one of major research projects for Shanghai General Land Use Planning Revision (2015(D)-002(F)-11).

Acknowledgments: We are very grateful to the referees and the editors for their helpful suggestions.

Conflicts of Interest: The authors declare no conflicts of interest.

\section{References}

1. Wu, H. Theory, Method and Practice of Land Consolidation and Rehabilitation; Geological Publishing House: Beijing, China, 2014. (In Chinese)

2. Zhang, Z.; Zhao, W. Evaluation methodology for resource and economic profits of land consolidation. Trans. Chin. Soc. Agric. Eng. 2011, 27, 295-299. (In Chinese)

3. Brink, A.V.D. The origins of Dutch rural planning: A study of the early history of land consolidation in the Netherlands. Plan. Perspect. 2008, 23, 427-453. [CrossRef]

4. Pasakarnis, G.; Maliene, V. Towards sustainable rural development in central and eastern Europe: Applying land consolidation. Land Use Policy 2010, 27, 545-549. [CrossRef]

5. Willem, K.; Altes, K.; Sang, B.I. Promoting rural development through the use of land consolidation: The case of Korea. Int. Plan. Stud. 2011, 16, 151-167.

6. Demetrioua, D.; Stillwell, J.; Seea, L. Land consolidation in Cyprus: Why is an integrated planning and decision support system required? Land Use Policy 2012, 29, 131-142. [CrossRef]

7. Jiang, G.; Wang, X.; Yun, W.; Zhang, R. A new system will lead to an optimal path of land consolidation spatial management in China. Land Use Policy 2015, 42, 27-37.

8. Haldrup, N.O. Agreement based land consolidation-In perspective of new modes of governance. Land Use Policy 2015, 46, 163-177. [CrossRef]

9. Gonzalez, X.P.; Alvarez, C.J.; Crecente, R. Evaluation of land distributions with Joint regard to plot size and shape. Agric. Syst. 2004, 82, 31-43. [CrossRef]

10. Shi, Y.; Yang, B. Reflections on and Countermeasures against Implementing Strategy of "Three Concentrations" in Suburban Districts of Shanghai. J. Tongji Univ. 2004, 15, 7-12. (In Chinese)

11. Shen, Y. Investigation of the Homestead Replacement Pilot in the Shanghai Suburbs. Shanghai Rural Econ. 2005, 27-29. (In Chinese). Available online: http:/ / www.cnki.com.cn/Article/CJFDTotal-SHNC200507007. $\mathrm{htm} /$ (accessed on 14 June 2018).

12. Rao, L. Shanghai's urban and rural construction land use and exploration. Shanghai Land Resour. 2016, 37, 28-30. (In Chinese)

13. Gu, S.; Liu, W.; Xia, J. Creating a new pattern of "land remediation +": Innovation and practice in Shanghai. China Land 2016, 42-44. (In Chinese) [CrossRef]

14. Tao, S.; Liu, J. Study on the optimization of land consolidation strategy in suburban areas of Shanghai. Low Carbon World 2017, 275-276. (In Chinese) [CrossRef]

15. Bronstert, A.; Vollmer, S.; Ihringer, J. A review of the impact of land consolidation on runoff production and flooding in Germany. Phys. Chem. Earth 1995, 20, 321-329. [CrossRef]

16. Lin, X.; Qi, C. Literature review of agricultural scale management and efficiency. Asian Agric. Res. 2016, 8, $1-5$.

17. Polpinit, P.; Boonchom, W.; Piewthongngam, K.; Chatavithee, P. Land consolidation of small-scale farms in preparation for a cane harvester. Comput. Electron. Agric. 2017, 142, 59-69.

18. Van den Noort, P.C. Land consolidation in the Netherlands. Land Use Policy 1987, 4, 11-13. [CrossRef] 
19. Chen, G. Utilization and renovation of land resources in the Netherlands. Nat. Resour. 1990, 12, 72-76. (In Chinese)

20. Cook, E.A. Urban landscape networks: An ecological planning framework. Landsc. Res. 1991, 16, 7-15. [CrossRef]

21. Xu, B. Land zoning: The mother of Japan's urban planning. Urban Plan. Int. 1994, 9, 25-34. (In Chinese)

22. Oduwaye, A.O. Urban landscape planning experience in Nigeria. Landsc. Urban Plan. 1998, 43, $133-142$. [CrossRef]

23. Jia, W.; Zhang, Z. Thoughts on the land consolidation and rehabilitation in Germany. Resour. Ind. 2005, 7, 77-79. (In Chinese)

24. Kupidura, A.; Łuczewski, M.; Home, R.; Kupidura, P. Public perceptions of rural landscapes in land consolidation procedures in Poland. Land Use Policy 2014, 39, 313-319. [CrossRef]

25. Guo, W.; Hou, X. From land consolidation to comprehensive planning-Summary and implications of the evolution of rural landscape renovation in the Netherlands. Landsc. Archit. 2016, 115-120. (In Chinese) [CrossRef]

26. Huang, C.W.; McDonald, R.I.; Seto, K.C. The importance of land governance for biodiversity conservation in an era of global urban expansion. Landsc. Urban Plan. 2018, 173, 44-50. [CrossRef]

27. Chen, B.; Gu, X.; Zhang, Z.; Zhou, X.; Chai, D. Land ecological consolidation and landscape design. China Land Sci. 2011, 25, 10-14. (In Chinese)

28. Liu, J.; Li, E.; Zhang, Z. Land consolidation strategy in Shanghai. Shanghai Land Resour. 2013, 34, 6-9. (In Chinese)

29. Lin, K.L. Determining key ecological indicators for urban land consolidation. Int. J. Strateg. Prop. Manag. 2010, 14, 89-103. [CrossRef]

30. Li, Y.; Wu, W.; Liu, Y. Land consolidation for rural sustainability in China: Practical reflections and policy implications. Land Use Policy 2018, 74, 137-141. [CrossRef]

31. Yu, P. Research on Remediation Potential in Arable Land Based on the Comprehensive Capacity Theory. Master's Thesis, Huazhong University of Science and Technology, Wuhan, China, 2013. (In Chinese)

32. Hu, X. Research on Land Comprehensive Consolidation Potential and Regionalization of Habahe County. Master's Thesis, Beijing Forestry University, Beijing, China, 2015. (In Chinese)

33. Ding, R. Potential Analysis and Countermeasures on Rural Residential Area Land Consolidation. Master's Thesis, Central China Normal University, Wuhan, China, 2017. (In Chinese)

34. Li, M. Research on Land Consolidation of Changfeng County: Based on the Contest of Overall Planning of Urban and Rural Development. Master's Thesis, Anhui Agricultural University, Hefei, China, 2012. (In Chinese)

35. Han, S. Study on Land Consolidation Potential in Bengbu City. Master's Thesis, Anhui Agricultural University, Hefei, China, 2013. (In Chinese)

36. Shi, Y.; Liu, D. Reduction in the amount of industrial land in Shanghai: Ideas and key problems. Shanghai Land Resour. 2016, 37, 1-4. (In Chinese)

37. Bonfanti, P.; Fregonese, A.; Sigura, M. Landscape analysis in areas affected by land consolidation. Landsc. Urban Plan. 1997, 37, 91-98. [CrossRef]

38. Crecente, R.; Alvarez, C.; Fra, U. Economic, social and environmental impact of land consolidation in Galicia. Land Use Policy 2002, 19, 135-147. [CrossRef]

39. Gozalez, X.P.; Marey, M.F.; Alvarez, C.J. Evaluation of productive rural land patterns with joint regard to the size, shape and dispersion of plots. Agric. Syst. 2007, 92, 52-62. [CrossRef]

40. Yaslioglu, E. Changes in farm management and agricultural activities and their effect on farmers' satisfaction from land consolidation: The case of Bursa-Karacabey, Turkey. Eur. Plan. Stud. 2009, 17, 327-340. [CrossRef]

41. Iscan, F. The effects of different land reallocation models applied in land consolidation projects on parcel transposition: Example of Karatepe village, Turkey. Sci. Res. Essays 2010, 5, 873-882.

42. Miranda, D.; Crecente, R.; Alvarez, M.F. Land consolidation in inland rural Galicia, N.W. Spain, since 1950: An example of the formulation and use of questions, criteria and indicators for evaluation of rural development policies. Land Use Policy 2010, 27, 763-771. [CrossRef]

43. Uyan, M.; Cay, T.; Inceyol, Y.; Hakli, H. Comparison of designed different land reallocation models in land consolidation: A case study in Konya/Turkey. Comput. Electron. Agric. 2015, 110, 249-258. [CrossRef] 
44. Johansen, P.H.; Ejrnæs, R.; Kronvang, B.; Olsen, J.V.; Præstholm, S.; Schou, J.S. Pursuing collective impact: A novel indicator-based approach to assessment of shared measurements when planning for multifunctional land consolidation. Land Use Policy 2018, 73, 102-114. [CrossRef]

45. Podhrázská, J.; Vaishar, A.; Toman, F.; Knotek, J.; Ševelová, M.; Stonawská, K.; Vasylchenko, A.; Karásek, P. Evaluation of Land Consolidation Process by Rural Stakeholders. Eur. Countrys. 2015, 7, 144-155. [CrossRef]

46. Allahyari, M.S.; Damalas, C.A.; Masouleh, Z.D.; Masouleh, Z.D.; Ghorbani, M. Land consolidation success in paddy fields of northern Iran: An assessment based on farmers' satisfaction. Land Use Policy 2018, 73, 95-101. [CrossRef]

47. Sayilan, H. Importance of land consolidation in the sustainable use of Turkey's rural land resources. Procedia Soc. Behav. Sci. 2014, 120, 248-256. [CrossRef]

48. Caya, T.; Uyanb, M. Evaluation of reallocation criteria in land consolidation studies using the analytic hierarchy process (AHP). Land Use Policy 2013, 30, 541-548. [CrossRef]

49. Luo, W.; Wu, X.; Wu, Y. Method and case study of performance evaluation on land consolidation projects based on matter-element model. Resour. Environ. Yangtze Basin 2011, 20, 1321-1326. (In Chinese)

50. Luo, W.; Wu, C.; Yang, J. Performance evaluation of land consolidation projects based on the matter-element method under "process logic" framework. Chin. Land Sci. 2010, 24, 55-61. (In Chinese)

51. Zhou, H.; Zhao, W.; Xu, W. Farmers' behavior of supervision and maintenance for land consolidation projects based on Lewin behavior model. Resour. Dev. Mark. 2017, 33, 129-133. (In Chinese)

52. Li, F.; Liu, Y. Analysis of influencing factors of farmers' participation behavior in different rural residential land consolidation stages. Trans. Chin. Soc. Agric. Eng. 2018, 34, 249-257. (In Chinese)

53. Wang, X.; Chen, C.; Xie, S. Study on the performance evaluation of land remediation project in Henan Province combined behavior with result. Geogr. Geo-Inf. Sci. 2014, 30, 88-93. (In Chinese)

54. Xie, Z. Study of Method and Application for Post-Evaluation of Land Consolidation Project. Master's Thesis, Xi'an University of Technology, Xi'an, China, 2009. (In Chinese)

55. Zhang, X.; Yang, J.; Wang, Z. Research on the index system of land consolidation projects based on the whole process of performance evaluation. Hubei Agric. Sci. 2015, 54, 2073-2079. (In Chinese)

56. Gu, X.; Zhou, X.; Lu, X. Pattern and evaluation for land consolidation of rural habitat in suburb of metropolis: A case study of Jinshan District. Shanghai. Econ. Geogr. 2009, 30, 832-835. (In Chinese)

57. Ni, N.; Guo, T. The performance evaluation of land reclamation project based on super efficiency DEA: A case study in Anhui Province. Chin. Agric. Sci. Bull. 2014, 30, 142-148. (In Chinese)

58. Zhang, Z.; Zhao, W. Effects of land consolidation on ecological environment. Trans. Chin. Soc. Agric. Eng. 2007, 23, 281-285. (In Chinese)

59. Yun, W.; Yang, X.; Cheng, F. Rural land renovation with metropolis features: Shanghai mode. Shanghai Land Resour. 2012, 33, 21-25. (In Chinese)

60. Zhang, C.; Long, T.; Lu, J. Study on land remediation model in the outskirts of metropolitan area: A case study of the Miaozhen suburban unit in Shanghai. China Land 2016, 40-41. (In Chinese) [CrossRef]

61. Long, T.; Wang, H.; Ma, J. Land consolidation mode based on the rural development in Shanghai: A case study of Heqing town, Pudong New Area. Acta Agric. Shanghai 2016, 32, 170-174. (In Chinese)

62. Gu, S.; Long, T.; Liu, J. Innovation and practice of overall land renovation: Taking Shanghai as an example. China Land 2017, 52-55. (In Chinese) [CrossRef]

63. Liu, J. An analysis of the Shanghai model of land consolidation. China Land 2017, 45-48. (In Chinese) [CrossRef]

64. Liu, X.; Yang, H.; Yun, W. Patterns of land consolidation promoting poverty alleviation in poor areas and its application. Trans. Chin. Soc. Agric. Eng. 2018, 34, 242-247. (In Chinese)

65. Ning, X.; Zhao, M. Changes in land use and landscape caused by land consolidation: A case study of Heqing Town in Shanghai. Resour. Environ. Yangtze Basin 2016, 25, 79-87. (In Chinese)

66. Gu, X.; Liu, J. Evaluation of the social effects of urban sightseeing agricultural land remediation projects. Resour. Sci. 2013, 35, 1549-1554. (In Chinese)

67. Yang, X.; Jin, X.; Guan, X.; Guo, B.; Zhou, Y. The spatial distribution of land consolidation projects in China from 2006 to 2012. Resour. Sci. 2013, 35, 1535-1541. (In Chinese)

68. Wei, X.; Liu, Y.; Wang, N. Spatial disparity pattern of land consolidation projects in Hubei Province. Trans. Chin. Soc. Agric. Eng. 2014, 30, 195-203. (In Chinese) 
69. Yang, J.; Wang, Z.; Yi, P.; Jin, G.; Hu, X. Spatial distribution of land consolidation projects and its correlation with the new countryside development program in Zhushan County. China Land Sci. 2014, 28, 62-70. (In Chinese)

70. You, C.; Zhou, Y.; Yu, L. An introduction of quantitative methods in landscape pattern fragmentation. Chin. Agric. Sci. Bull. 2006, 22, 146-151. (In Chinese)

71. Wu, J. Landscape Ecology: Pattern, Process, Scale and Hierarchy, 2nd ed.; Higher Education Press: Beijing, China, 2007. (In Chinese)

72. Shi, J.; Yuan, C. Effect of reduction of construction land on landscape pattern and function in the city suburb: A case of Qingxi region in Shanghai. Shanghai Land Resour. 2016, 37, 19-22. (In Chinese)

73. Saaty, T.L. The Analytic Hierarchy Process: Planning, Priority Setting, Resource Allocation; McGraw-Hill: New York, NY, USA, 1980.

74. Mohsen, S.; Mohammad, A.; Reza, K.; Mohammad, K. Mineral processing plant location using the analytic hierarchy process-A case study: The Sangan iron ore mine (phase 1). Int. J. Min. Sci. Technol. 2010, 20, 691-695.

75. Xu, J. Mathematical Methods in Contemporary Geography, 2nd ed.; Higher Education Press: Beijing, China, 2002; pp. 224-225. (In Chinese)

76. Toneva, P.; Peukert, W. A general approach for the characterization of fragmentation problems. Adv. Powder Technol. 2007, 18, 39-51. [CrossRef]

77. Zhu, Y.D.; Zhang, J.W.; Wang, C.; Liu, Z.J. Fragmentation degree research based on fileâs layout. Appl. Mech. Mater. 2011, 80, 1217-1225.

78. Roch, L.; Jaeger, J.A. Monitoring an ecosystem at risk: What is the degree of grassland fragmentation in the Canadian Prairies? Environ. Monit. Assess. 2014, 186, 2505-2534. [CrossRef] [PubMed]

79. Liu, Y.; Feng, Y.; Zhao, Z.; Zhang, Q.; Su, S. Socioeconomic drivers of forest loss and fragmentation: A comparison between different land use planning schemes and policy implications. Land Use Policy 2016, 54, 58-68. [CrossRef]

80. Pascual-Hortal, L.; Saura, S. Comparison and development of new graph-based landscape connectivity indices: Towards the priorization of habitat patches and corridors for conservation. Landsc. Ecol. 2006, 21, 959-967. [CrossRef]

81. Bunn, A.G.; Urban, D.L.; Keitt, T.H. Landscape connectivity: A conservation application of graph theory. J. Environ. Manag. 2000, 59, 265-278. [CrossRef]

82. Kindlmann, P.; Burel, F. Connectivity measures: A review. Landsc. Ecol. 2008, 23, 879-890. [CrossRef]

83. Fu, W.; Liu, S.L.; Degloria, S.D.; Dong, S.K.; Beazley, R. Characterizing the "fragmentation-barrier" effect of road networks on landscape connectivity: A case study in Xishuangbanna, Southwest China. Landsc. Urban Plan. 2010, 95, 122-129. [CrossRef]

84. Ersoy, E. Landscape Ecology Practices in Planning: Landscape Connectivity and Urban Networks. In Sustainable Urbanization; Ergen, M., Ed.; UN Habitat: Nairobi, Kenya, 2016; pp. 291-316.

85. Hu, T.; Yang, Z. Method for ecological benefit assessment of rural land consolidation. Trans. Chin. Soc. Agric. Eng. 2004, 20, 275-280. (In Chinese)

86. Huylenbroeck, G.; Coelho, J.C.; Pinto, P.A. Evaluation of land consolidation projects (LCPs): A multidisciplinary approach. J. Rural Stud. 1996, 12, 207-310. [CrossRef]

87. Castro Coellho, J.; Aguiar Pinto, P. A systems approach for the estimation of the effects of land consolidation projects (LCPs): A model and its application. Agric. Syst. 2001, 68, 179-195. [CrossRef]

88. Sklenicka, P. Applying evaluation criteria for the land consolidation effect to three contrasting study areas in Czech Republic. Land Use Policy 2006, 23, 502-510. [CrossRef]

89. Kwinta, A.; Gniadek, J. The description of parcel geometry and its application in terms of land consolidation planning. Comput. Electron. Agric. 2017, 136, 117-124. [CrossRef]

(C) 2018 by the authors. Licensee MDPI, Basel, Switzerland. This article is an open access article distributed under the terms and conditions of the Creative Commons Attribution (CC BY) license (http://creativecommons.org/licenses/by/4.0/). 